\title{
The Gravity of a Crime in Selection \\ and Application of the Remand \\ in Custody as a Pre-trial Restraint: \\ Problems of Legal Regulation \\ and Current Practice
}

\author{
Aleksei B. Sudnitsyn* \\ Siberian Juridical Institute of MIA of Russia \\ 20 Rokossovskogo Str., Krasnoyarsk, 660131, Russia
}

Received 20.09.2016, received in revised form 19.11.2016, accepted 15.12.2016

The article examines the impact of the crime severity on application of the remand in custody basing on the analysis of works of procedural law researchers, rules of law, investigation and judicial practice, including the European Human Rights miracle. The article considers the problems of legal regulation and the current practice. The author concludes and provides recommendations for law enforcers how to differentiate between the data on the severity of the crime and similar concepts when deciding to apply the remand of custody, as well the proper use of such data in practice in order to comply with the requirements of the law, the adoption of lawful, reasoned and motivated decision regarding the remand of custody.

Keywords: pre-trial restraints, selection and application of pre-trial restraints, remand in custody, grounds, conditions, data confirming grounds and conditions, data on the commitment of the crime of a certain gravity degree.

DOI: 10.17516/1997-1370-0028.

Research area: law.

\section{Introduction}

into the research problem

The presumption of freedom recognized by the world community acting against any person establishes that the normal condition of the man requires them to be anywhere outside the places of confinement. At the same time, the implementation of appointment of the criminal process is not possible without the provision of competent authorities and officials with the authority to apply the state coercion, including restraints substantially limiting the freedom and inviolability of a person. Among these measures, the remand in custody as a preventive measure occupies special place due to the high efficiency of the measure (in comparison with other pre-trial restraints), as well as its severity in relation to the person taken into custody. In order to ensure a

(C) Siberian Federal University. All rights reserved

* Corresponding author E-mail address: ab_sudnitsyn@mail.ru 
balance between the interests of an individual and the need for effective implementation of criminal justice, the legislator has established a system of grounds, conditions and circumstances that determine the possibility and necessity of selection and application of the remand in custody.

One of the elements of such a system is the gravity of the crime, which should be taken into account in the selection and application of the pre-trial restraints (Article 99, Code of Criminal Procedure of the Russian Federation). The legislator states it is unacceptable to refer to the gravity of the crime as the basis for the selection of a pre-trial measure (Article 97, Code of Criminal Procedure of the Russian Federation). The generalization of the selection practice of the remand in custody, the results of surveying, interviewing of investigators and interrogative officers revealed that for officials, on the whole, the severity of the crime itself is the basis for the selection of the remand in custody. And this opinion is quite common, despite the fact that the reference to the gravity of the accusation as the grounds for selecting the remand in custody is recognized by the courts as a serious lack of argument ${ }^{1}$.

Moreover, this approach leads to the identification of the grounds, conditions and circumstances of the selection of the remand in custody. The result is the substitution of the requirements defined by the law (for example, the grounds for the selection of pre-trial restraints - the circumstances that should be considered when choosing a pre-trial restraint). As a result, the decision to apply a pre-trial restraint may be found to be unlawful and unreasonable.

\section{The basis for research, problem statement, concept}

However, the seriousness of the offense the person is imputed with, in relation to whom the selection of the remand in custody is decided, certainly has value and cannot be ignored.

Thus, in the theory of criminal procedure the opinion about the possible misconduct of the accused, based on the presumption is quite common according to which the very severity of the crime and the severity of the possible sentence may encourage a person to hide or prevent determination of the truth ${ }^{2}$.

It should be outlined that the Code of Criminal Procedure of RSFSR of 1960 even though did not determine the severity of the crime as the basis for the selection of the remand in custody, but provided the application of this restraint on the grounds of the gravity of the crime (Part 2, Article 96, Code of Criminal Procedure of RSFSR). This legislative position can be explained by the argument that "the accusation of a dangerous criminal offense for which, as a general rule, a severe penalty is provided for, is fraught with a greater probability that the accused will evade the investigation and the trial"'3.

Moreover, the criminal procedural legislation delineates the selection of the remand in custody when accusing a person in committing crimes of various categories (e.g. minor crime and extremely serious one). In particular, the Code of Criminal Procedure of the Russian Federation sets out a number of additional conditions that are required for the selection of the remand in custody, when it comes to crimes of less serious categories, or certain types of them (Parts 1, 1', 2 , Article 108, Parts 2, 3, Article 109 of the Code of Criminal Procedure of the Russian Federation).

Certainly, the given statements emphasize the need to consider the severity of the crime in deciding on the selection of the remand in custody. But such regulation takes into account not all possible situations which arise in law enforcement. For example, the investigation of serious and extremely serious crimes determines a person suspected of committing the crime, 
there is the need to choose the most rigorous pretrial restraints, but there are no comprehensive data for complete confirmation of selecting the remand in custody. For example, in 2012, in the suburban town of Dolgoprudny Mrs. Ryabkova led her own infant children to the balcony of the fifteenth floor and threw them over the fence; as a result of the fall the children died on the $\operatorname{spot}^{4}$. In this situation, Mrs. Ryabkova did not try to escape from the scene of the crime, did not express intention to hide from the investigation and the trial, did not buy tickets for the purpose of travelling to another place, etc. Thus, specific factual circumstances confirming the presence of the grounds under Par. 1, Part 1, Article 97 of the Code of Criminal Procedure, were not seen at the initial stage of the investigation.

In this regard, the issue of the impact of the crime gravity on the probability of negative consequences listed in Par. 1, Part 1, Article 97 of the Code of Criminal Procedure, and the decision on the election of the remand in custody is quite urgent.

\section{Discussion}

To resolve the indicated problematic aspect, the previously given theoretical position and the evolving judicial and investigative practice, including the European Court of Human Rights (hereinafter referred to as ECHR) should be taken into account.

ECHR practice comes from the fact that the severity of the possible punishment is an important factor in assessing the risk of misconduct of the suspect ${ }^{5}$ that determines the selection of the remand in custody at the initial stages of the proceedings (hereinafter in italics, author's comments) ${ }^{6}$.

The Supreme Court of the Russian Federation also pays attention to this fact? ${ }^{7}$. The latter actually differentiates the degree of the decision validity in relation to the remand in custody depending on the period of investigation. Thus, paragraphs 5,21 of the decree provide for that the grounds for the remand in custody (Par. 1, Part 1, Art. 97 of the Code of Criminal Procedure), at the initial stages of proceedings can be confirmed only by the severity of the accusation presented and the possibility of punishment in the form of longterm imprisonment.

The approach formulated by the Supreme Court of the Russian Federation, which takes into account situations occurring in practice, when at the initial stages of the proceedings and in deciding on the selection of the remand in custody law enforcers are in terms of lack of information, should be assessed positively. However, it is necessary to make some clarifications.

The wording used by the Supreme Court - gravity of the accusation - should not be interpreted literally, and be associated only with the procedure of the involvement as the accused. The law provides for the possibility of selecting a preventive measure also in the relation to the suspect (Article 100 of the Code of Criminal Procedure). Therefore, it is more expedient to talk about the seriousness of the offense, the commission of which the person is suspected in or accused of, on which a decision on the selection of the remand in custody is taken.

The need to confirm the grounds under Par. 1, Part 1, Article 97 of the Code of Criminal Procedure, with the severity of the crime and possible punishment may take place not only at the initial stage, but also at later stages of the proceedings. This need can be caused, for example, by the fact that in the criminal proceedings there is information about the person subject to be charged as the accused, but there are no available comprehensive data for full justification of the decision on the selection of the remand in custody in the general order (despite previously conducted proceedings). Therefore, the investigator may be in the conditions similar 
to those previously noted, related to the issue of selecting the remand in custody at the initial stage of the criminal proceedings. In this connection, we should talk about the possibility to make a special emphasis on the severity of the crime at the subsequent stages of the proceedings with the initial selection of remand in custody, and possible punishment for the confirmation of the grounds under Par. 1, Part 1, Article 97 of the Code of Criminal Procedure.

The third clarification. Upon confirmation of the grounds under Par. 1, Part 1, Article 97 of the Code of Criminal Procedure, at the initial stages it is necessary to emphasize the social danger of the crime. It is suggested due to the fact that the crimes relating to the same category of gravity (Art. 15 of the Criminal Code), may vary in terms of public danger. For example, the illegal sale of drugs (heroin) in the amount of $1,000 \mathrm{~g}$ and illegal sale of drugs (heroin) in the amount of 10,000 t may be qualified equally: Part 5, Article $228^{1}$ of the Criminal Code. But it is clear that the public danger of these crimes is different.

\section{Main conclusions}

Talking about how the severity of the crime confirms the grounds (Par. 1, Part 1, Article 97 of the Code of Criminal Procedure) for selecting pre-trial restraints, we should remember: it is only the confirmation of the grounds. For selection or application of the remand in custody, other circumstances are required. For example, Article 99 of the Code of Criminal Procedure provides that in deciding on the selection of a pre-trial restraint and determining its type in the presence of grounds, the circumstances referred to in this article should be also taken into account. In addition to the circumstances under Article 99 of the Code of Criminal Procedure, a number of conditions should be met: a reasonable charge (suspicion) expressed in a procedural act entailing the emergence of the corresponding procedural status; confirmation of the impossibility to select another, softer pretrial restraint (Part 1, Article 108 of the Code of Criminal Procedure), etc.

Thus, the severity of the crime can confirm the grounds (Par. 1, Part 1, Article 97 of the Code of Criminal Procedure) in case of the initial selection of the remand in custody and high social danger of the crime. The above understanding of the severity of the crime allows to differentiate them from the conditions of choosing pre-trial restraints, the circumstances taken into account when selecting pre-trial restraints and use them properly in practice. This will facilitate compliance with the requirements of the law, the adoption of lawful and reasoned decision, further positive assessment of the taken decision and the unity of practice ${ }^{8}$.

\footnotetext{
See: Case of Dirdizov against the Russian Federation: Resolution of the European Court of Human Rights dated November 27, 2012. Bulletin of the European Court of Human Rights, 2013, No. 9, etc.

2 Petrukhin, I.L. (1989). Neprikosnovennost' lichnosti i prinuzhdenie v ugolovnom protsesse [Personal immunity and coercion in the criminal proceedings]. Moscow, P. 107

3 Chuvilev, A.A. (1989). Zakliuchenie pod strachu v kachestve mery presecheniia: lektsiia [Remand in custody as a pre-trial restraint: lecture]. Moscow, P.7.

4 See: In Moscow region a mother threw her children out of the balcony on the $15^{\text {th }}$ floor (June 24, 2012). Available at: http:// www.vesti.ru/doc.html?id=829412 (accessed 01.06.2015).

5 See for example: Case of Yakovlev v. Russia: Resolution of the European Court of Human Rights dated April 29, 2010. Bulletin of the European Court of Human Rights, 2010, No. 11 (par. 71).

6 See for example: Case of Samoylov v. Russia: Resolution of the European Court of Human Rights dated January 24, 2012. Bulletin of the European Court of Human Rights, 2012, No. 11 (par. 109); Case of Pyatkov v. Russia: Resolution of the European Court of Human Rights dated November 13, 2012. Bulletin of the European Court of Human Rights, 2013, No. 12, (par. 112); Case of Korolev v. Russia: Resolution of the European Court of Human Rights dated November 13, 2012. Bulletin of the European Court of Human Rights, 2012, No. 12, (par. 95); etc.

7 See: O praktike primeneniia sudami zakonodatel'stva o merakh presecheniia v vide zakliucheniia pod strazhu, domashnego aresta i zaloga: Postanovlenie Plenuma Verkhovnogo Suda RF ot 19 dekabria 2013 No. 41 [Court practice of applying
} 
the law on pre-trial restraints such as remand in custody, home imprisonment and bail: Decree No. 41 of the Supreme Court Plenum of the Russian Federation dated December 19, 2013] (2013). Rossiiskaia gazeta, Issue of December 27, 2013.

8 See: Sudnitsyn, A.B. \& Voronov, D.A. (2014). Zakonnost' i obosnovannost' mery presecheniia v vide zakliucheniia pod strazhu: uchebnoe posobie [Legality and justification of the remand in custody: student's book]. Krasnoyarsk, Siberian Judicial Institute of FDCS of Russia, 96 p.

\section{References}

Case of Dirdizov v. Russia: Resolution of the European Court of Human Rights dated November 27, 2012. Bulletin of the European Court of Human Rights, 2013, No. 9.

Case of Korolev v. Russia: Resolution of the European Court of Human Rights dated November 13, 2012. Bulletin of the European Court of Human Rights, 2012, No. 12.

Case of Pyatkov v. Russia: Resolution of the European Court of Human Rights dated November 13, 2012. Bulletin of the European Court of Human Rights, 2013, No. 12.

Case of Samoylov v. Russia: Resolution of the European Court of Human Rights dated January 24, 2012. Bulletin of the European Court of Human Rights, 2012, No. 11.

Case of Yakovlev v. Russia: Resolution of the European Court of Human Rights dated April 29, 2010. Bulletin of the European Court of Human Rights, 2010, No. 11.

Chuvilev, A.A. (1989). Zakliuchenie pod strachu v kachestve mery presecheniia: lektsiia [Remand in custody as a pre-trial restraint: lecture]. Moscow, $48 \mathrm{p}$.

In Moscow region a mother threw her children out of the balcony on the $15^{\text {th }}$ floor (June 24, 2012). Available at: http://www.vesti.ru/doc.html?id=829412 (accessed 01.06.2015).

O praktike primeneniia sudami zakonodatel'stva o merakh presecheniia v vide zakliucheniia pod strazhu, domashnego aresta i zaloga: Postanovlenie Plenuma Verkhovnogo Suda RF ot 19 dekabria 2013 No. 41 [Court practice of applying the law on pre-trial restraints such as remand in custody, home imprisonment and bail: Decree No. 41 of the Supreme Court Plenum of the Russian Federation dated December 19, 2013] (2013). Rossiiskaia gazeta, Issue of December 27, 2013.

Petrukhin, I.L. (1989). Neprikosnovennost' lichnosti I prinuzhdenie v ugolovnom protsesse [Personal immunity and coercion in the criminal proceedings]. Moscow, $256 \mathrm{p}$.

Sudnitsyn, A.B. \& Voronov, D.A. (2014). Zakonnost' i obosnovannost' mery presecheniia $v$ vide zakliucheniia pod strazhu: uchebnoe posobie [Legality and justification of the remand in custody: student's book]. Krasnoyarsk, Siberian Judicial Institute of FDCS of Russia, 96 p. 


\title{
Тяжесть преступления при избрании \\ и применении меры пресечения \\ в виде заключения под стражу: \\ проблемы правового регулирования \\ и складывающейся практики
}

\author{
А.Б. Судницын \\ Сибирский юридический институт \\ МВД России (2. Красноярск)
}

Россия, 660131, Красноярск, ул. Рокоссовского, 20

В статье на основе анализа трудов ученых-процессуалистов, норм закона, следственной и судебной практики, в том числе Европейского чуда по правам человека, рассматривается влияние тяжести преступления при принятии решения об избрании меры пресечения в виде заключения под стражу. Обозначены проблемы правового регулирования и складывающейся практики. Сформулированы выводы и рекомендации правоприменителям по разграничению данных о тяжести преступления при принятии решения об избрании меры пресечения от смежных понятий. А также по надлежащему их использованию в практической деятельности в целях соблюдения требований закона, принятия законного, обоснованного и мотивированного решения об избрании меры пресечения в виде заключения под стражу.

Ключевые слова: меры пресечения, избрание и применение мер пресечения, заключение под стражу, основания, условия, данные, подтверждающие наличие оснований и условий, данные о совершении преступления определенной степени тяжести.

Научная специиальность: 12.00.00 - юридические науки. 